\title{
Synthesis, characterization, and in vitro antimicrobial activity of organotin(IV) complexes with triazolo-pyrimidine ligands containing exocyclic oxygen atoms
}

\author{
M. Assunta Girasolo a, Clelia Di Salvo a , Domenico Schillaci ${ }^{\mathrm{b}}$, Giampaolo Barone ${ }^{\mathrm{a}}$, \\ Arturo Silvestri ${ }^{\text {a }}$, Giuseppe Ruisi ${ }^{\mathrm{a}, *}$ \\ ${ }^{a}$ Dipartimento di Chimica Inorganica e Analitica Stanislao Cannizzaro, Università di Palermo, Viale delle Scienze, Edificio 17, I-90128 Palermo, Italy \\ ${ }^{\mathrm{b}}$ Dipartimento di Chimica e Tecnologia Farmaceutiche, Università di Palermo, via Archirafi 32, I-90123 Palermo, Italy
}

Received 18 May 2005; received in revised form 20 July 2005; accepted 20 July 2005

Available online 2 September 2005

\begin{abstract}
Tri-organotin(IV) complexes of the triazolo-pyrimidine derivatives 4,5-dihydro-5-oxo-[1,2,4]triazolo-[1,5a]pyrimidine (5HtpO), 4,7-dihydro-5-methyl-7-oxo-[1,2,4]triazolo-[1,5a]pyrimidine (HmtpO), and 4,5,6,7-tetrahydro-5,7-dioxo-[1,2,4]triazolo-[1,5a]pyrimidine $\left(\mathrm{H}_{2} \mathrm{tpO}_{2}\right)$, and the diorganotin derivative $n-\mathrm{Bu}_{2} \mathrm{Sn}\left(\mathrm{tpO}_{2}\right)$, were synthesized and characterized by means of infrared and ${ }^{119} \mathrm{Sn}$ Mössbauer spectroscopy. In all the complexes obtained the triazolopyrimidines act as multidentate ligands producing polymeric structures.

A trigonal bipyramidal arrangement of the ligands around the tin atom is proposed for triorganotin(IV) derivatives, with organic groups on the equatorial plane and bridging anionic ligands.

DFT calculations were performed on the structure of $\mathrm{H}_{2} \mathrm{tpO}_{2}$ and on its mono- an di-anions, to investigate their harmonic vibrational modes. The observed trend of the experimental and calculated carbonyl stretching frequencies furnishes a support for the interpretation of the structure of the organotin(IV) complexes obtained with this ligand.

The structure of $n-\mathrm{Bu}_{2} \mathrm{Sn}\left(\mathrm{tpO}_{2}\right)$ was elucidated by quantum chemical calculations, performed on a model system of the polymeric complex by a two layers ONIOM method. The combined experimental and theoretical results obtained support for a trans- $n$ - $\mathrm{Bu}_{2}$ distorted octahedral geometry, with the $\mathrm{tpO}_{2}^{2-}$ units acting as bis-chelate ligands bridging the diorganotin(IV) moieties, and with the $\mathrm{N}(1) \mathrm{O}(7)$ and $\mathrm{N}(4) \mathrm{O}(5)$ chelating groups in the equatorial plane showing a cis $-\mathrm{O}_{2}$, or $c i s-\mathrm{N}_{2}$, coordination.

In vitro antimicrobial tests were performed on $n$ - $\mathrm{Bu}_{3} \mathrm{Sn}\left(\mathrm{HtpO}_{2}\right)$ and $\mathrm{Ph}_{3} \mathrm{Sn}\left(\mathrm{HtpO}_{2}\right)$, and a good antifungal and antibiofilm activity was observed, in particular for $n-\mathrm{Bu}_{3} \mathrm{Sn}(\mathrm{HtpO})_{2}$.
\end{abstract}

(C) 2005 Elsevier B.V. All rights reserved.

Keywords: Triazolopyrimidine; Organotin(IV); Mössbauer; DFT calculations; Antimicrobial activity

\section{Introduction}

The coordination chemistry of heterocyclic ligands is a field of increasing interest. Between them, 1,2,4-triazole-[1,5-a]pyrimidine (tp) derivatives are particularly studied because they are isomers of purines, and their

\footnotetext{
${ }^{*}$ Corresponding author. Tel.: +39091 489369; fax: +39091427584.

E-mail address: gruisi@unipa.it (G. Ruisi).
}

coordination compounds can be considered as model systems for metal-ligand interactions observed in biological systems [1]. Triazolopyrimidines are versatile ligands for metal ions, the resulting complexes giving rise to a variety of structures including homo- and hetero-polynuclear compounds $[1,2]$. Further interest in the field comes from the search of new compounds with antimicrobial activity [1]. Many transition metal complexes of triazolopyrimidines were so far studied, while 

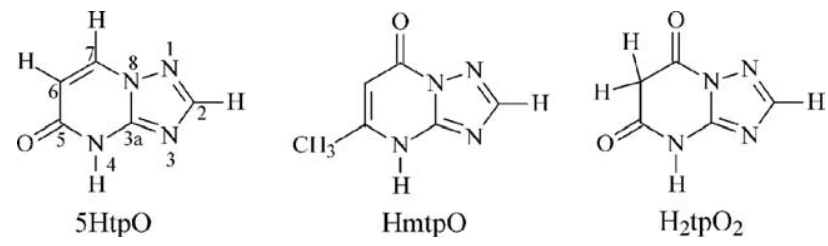

Fig. 1. The more stable tautomeric forms of the ligands employed and the atom numbering scheme.

no work has been reported, to our knowledge, on their organotin(IV) derivatives, despite the ascertained biocide properties of organotin(IV) compounds [3]. Here, we report on the synthesis and spectroscopic characterization of $\mathrm{R}_{3} \mathrm{Sn}(\mathrm{IV}) \quad(\mathrm{R}=\mathrm{Me}, n-\mathrm{Bu}, \mathrm{Ph})$ and $n-\mathrm{Bu}_{2}-\mathrm{Sn}(\mathrm{IV})$ complexes of 4,5-dihydro-5-oxo-[1, $2,4]$ triazolo-[1,5a]pyrimidine $(5 \mathrm{HtpO})$, 4,7-dihydro-5methyl-7-oxo-[1,2,4]triazolo-[1,5a]pyrimidine (HmtpO), and 4,5,6,7-tetrahydro-5,7-dioxo-[1,2,4]triazolo-[1,5a]pyrimidine $\left(\mathrm{H}_{2} \mathrm{tpO} \mathrm{O}_{2}\right)$, see Fig. 1 .

We also report on in vitro antimicrobial tests performed on $n-\mathrm{Bu}_{3} \mathrm{Sn}\left(\mathrm{HtpO}_{2}\right)$ and $\mathrm{Ph}_{3} \mathrm{Sn}\left(\mathrm{HtpO}_{2}\right)$.

The presence of oxygen heteroatoms furnishes interesting properties to the oxo-derivatives of $t p$, in particular it improves: (i) their acidic strength and (ii) the coordination capability of the nitrogen atom N(4), even in the molecular ligands by keto-enolic tautomerism [4].

\section{Experimental}

\subsection{Materials and methods}

The products employed in the present study were obtained from C. Erba (Milan, Italy) and Sigma-Aldrich (Milan, Italy), unless otherwise stated, and used without further purification except methanol, which was distilled over magnesium. The ligands $5 \mathrm{HtpO}$ and $\mathrm{H}_{2} \mathrm{tpO}_{2}$ were synthesized as previously reported $[5,6]$.

Carbon, hydrogen and nitrogen assays were carried out with a Vario EL III elemental analyzer (Elementar GmbH, Germany).

The Mössbauer (nuclear $\gamma$ resonance) spectrometers, the related instrumentation and data reduction procedures were as previously described [7]. A $10 \mathrm{mCi} \mathrm{Ca}^{119} \mathrm{~S}$ $\mathrm{nO}_{3}$ source (RITVERC GmbH, St. Petersburg, Russia) was employed. The isomer shifts are relative to room temperature $\mathrm{Ca}^{119} \mathrm{SnO}_{3}$. Solution samples were quickly frozen by immersion in liquid nitrogen in order to obtain glassy absorbers. The ${ }^{119} \mathrm{Sn}$ Mössbauer parameters are reported in Tables 1 and 2 .

${ }^{13} \mathrm{C}$ NMR spectra were recorded at $63 \mathrm{MHz}$ with a Bruker AC 250 E instrument. Spectral data are reported in Table 2.

Infrared spectra (nujol and hexachlorobutadiene mulls, CsI windows) were recorded with an FT-IR spec-
Table 1

${ }^{119} \mathrm{Sn}$ Mössbauer parameters of organotin(IV) complexes in the solid state $^{\mathrm{a}}$

\begin{tabular}{llll}
\hline Compound & $\delta^{\mathrm{b}}\left(\mathrm{mm} \mathrm{s}^{-1}\right)$ & $\Delta E^{\mathrm{c}}\left(\mathrm{mm} \mathrm{s}^{-1}\right)$ & $\Gamma^{\mathrm{d}}\left(\mathrm{mm} \mathrm{s}^{-1}\right)$ \\
\hline $\mathrm{Me}_{3} \mathrm{Sn}(5 \mathrm{tpO})(\mathbf{1})$ & 1.28 & 3.42 & 0.81 \\
$n-\mathrm{Bu}_{3} \mathrm{Sn}(5 \mathrm{tpO})(\mathbf{2})$ & 1.40 & 3.47 & 0.86 \\
$\mathrm{Me}_{3} \mathrm{Sn}(\mathrm{mtpO})(\mathbf{3})$ & 1.30 & 3.42 & 0.90 \\
$n-\mathrm{Bu}_{3} \mathrm{Sn}(\mathrm{mtpO})(\mathbf{4})$ & 1.44 & 3.63 & 0.91 \\
$n-\mathrm{Bu}_{3} \mathrm{Sn}\left(\mathrm{HtpO}_{2}\right)(\mathbf{5})$ & 1.48 & 3.90 & 0.87 \\
$\mathrm{Ph}_{3} \mathrm{Sn}\left(\mathrm{HtpO}_{2}\right)(\mathbf{6})$ & 1.28 & 3.35 & 0.92 \\
$n-\mathrm{Bu}_{2} \mathrm{Sn}\left(\mathrm{tpO}_{2}\right)(\mathbf{7})$ & 1.54 & 4.43 & 0.89 \\
\hline
\end{tabular}

a At liquid-nitrogen temperature.

b Isomer shift with respect to room-temperature $\mathrm{CaSnO}_{3}$.

${ }^{\mathrm{c}}$ Nuclear quadrupole splitting.

${ }^{d}$ Full-width at half-height of the resonant peaks.

trometer Perkin-Elmer Spectrum One. Selected bands are reported in Table 3.

\subsection{Synthesis of the complexes}

The complexes were obtained by reacting the proper organotin compound ( $2 \mathrm{mmol}$ ) with the triazolo-pyrimidine derivative $(2 \mathrm{mmol})$ in methanol $(20 \mathrm{~mL})$, as below specified.

$\left[\mathrm{Me}_{3} \mathrm{Sn}(5 \mathrm{tpO})\right](\mathbf{1}): \mathrm{Me}_{3} \mathrm{SnOH}+5 \mathrm{HtpO}$; the solution was refluxed for $3 \mathrm{~h}$, and left at RT overnight. A white solid precipitated, which was filtered off, washed and dried in vacuo. m.p. 225-226 ${ }^{\circ} \mathrm{C}$. Anal. Calc. for $\mathrm{C}_{8} \mathrm{H}_{12} \mathrm{~N}_{4} \mathrm{OSn}\left(298.921 \mathrm{~g} \mathrm{~mol}^{-1}\right) \mathrm{C}, 32.15 ; \mathrm{H}, 4.05 ; \mathrm{N}$, 18.74. Found: C, 32.98; H, 3.89; N, 18.20\%.

$\left[n-\mathrm{Bu}_{3} \mathrm{Sn}(5 \mathrm{tpO})\right]$ (2): $n-\mathrm{Bu}_{3} \mathrm{SnOCH}_{3}+5 \mathrm{HtpO}$; the solution was refluxed for $3 \mathrm{~h}$, then concentrated by evaporation of the solvent in vacuo. An oil was obtained which gave a white crystalline product by treatment with petroleum ether $\left(40-60{ }^{\circ} \mathrm{C}\right)$. m.p. $105-108{ }^{\circ} \mathrm{C}$. Anal. Calc. for $\mathrm{C}_{17} \mathrm{H}_{30} \mathrm{~N}_{4} \mathrm{OSn}\left(425.164 \mathrm{~g} \mathrm{~mol}^{-1}\right) \mathrm{C}, 48.03 ; \mathrm{H}$, 7.11; N, 13.18. Found: C, 47.69; H, 7.14; N, 12.63\%.

$\left[\mathrm{Me}_{3} \mathrm{Sn}(\mathrm{mtpO})\right](3): \mathrm{Me}_{3} \mathrm{SnOH}+\mathrm{HmtpO}$; the solution was refluxed for $1 \mathrm{~h}$, then concentrated in vacuo. A white solid product was obtained which was filtered off and dried in vacuo. m.p. $270-273{ }^{\circ} \mathrm{C}$. Anal. Calc. for $\mathrm{C}_{9} \mathrm{H}_{14} \mathrm{~N}_{4} \mathrm{OSn}\left(312.948 \mathrm{~g} \mathrm{~mol}^{-1}\right) \mathrm{C}, 34.54 ; \mathrm{H}, 4.51$; N, 17.90. Found: C, 33.98; H, 4.24; N, 18.50\%.

$\left[n-\mathrm{Bu}_{3} \mathrm{Sn}(\mathrm{mtpO})\right](4): n-\mathrm{Bu}_{3} \mathrm{SnOCH}_{3}+\mathrm{HmtpO}$; the solution was stirred for $1 \mathrm{~h}$, then concentrated in vacuo. A white solid product was obtained which was filtered off and dried in vacuo. The product is pasty at room temperature. m.p. 93-94 ${ }^{\circ} \mathrm{C}$. Anal. Calc. for $\mathrm{C}_{18} \mathrm{H}_{32} \mathrm{~N}_{4} \mathrm{OSn}$ (439.191 $\mathrm{g} \mathrm{mol}^{-1}$ ) C, 49.23; H, 7.34; N, 12.76. Found: C, 49.09; H, 7.98; N, 12.87\%.

$\left[n-\mathrm{Bu}_{3} \mathrm{Sn}\left(\mathrm{HtpO}_{2}\right)\right](5): n-\mathrm{Bu}_{3} \mathrm{SnOCH}_{3}+\mathrm{H}_{2} \mathrm{pO}_{2}$; the solution was refluxed for $1 \mathrm{~h}$, then concentrated in vacuo. An oil was obtained which gave a white solid product when dried in vacuo. m.p. $164-166{ }^{\circ} \mathrm{C}$. Anal. Calc. for $\mathrm{C}_{17} \mathrm{H}_{29} \mathrm{~N}_{4} \mathrm{O}_{2} \mathrm{Sn}$ (441.164 $\mathrm{g} \mathrm{mol}^{-1}$ ) C, 46.28; H, 6.85; N, 12.70; C, 45.94; H, 7.09; N, 12.82 . 
Table 2

Solution phase spectroscopic data of triorganotin(IV) derivatives of $\mathrm{H}_{2} \mathrm{tpO}_{2}$

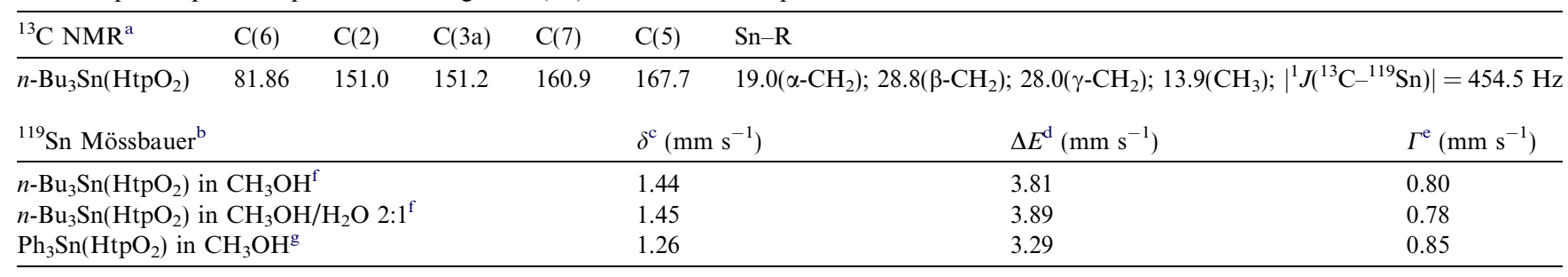

${ }^{\mathrm{a}}$ in $\mathrm{CD}_{3} \mathrm{OD} ; \delta$ in ppm from internal TMS.

${ }^{\mathrm{b}}$ Frozen solutions at liquid-nitrogen temperature.

${ }^{c}$ Isomer shift with respect to room-temperature $\mathrm{CaSnO}_{3}$.

d Nuclear quadrupole splitting.

e Full-width at half-height of the resonant peaks.

f $0.1 \mathrm{M}$ solution.

g Saturated solution.

Table 3

Selected IR bands $\left(\mathrm{cm}^{-1}\right)$ for organotin(IV) complexes and ligands

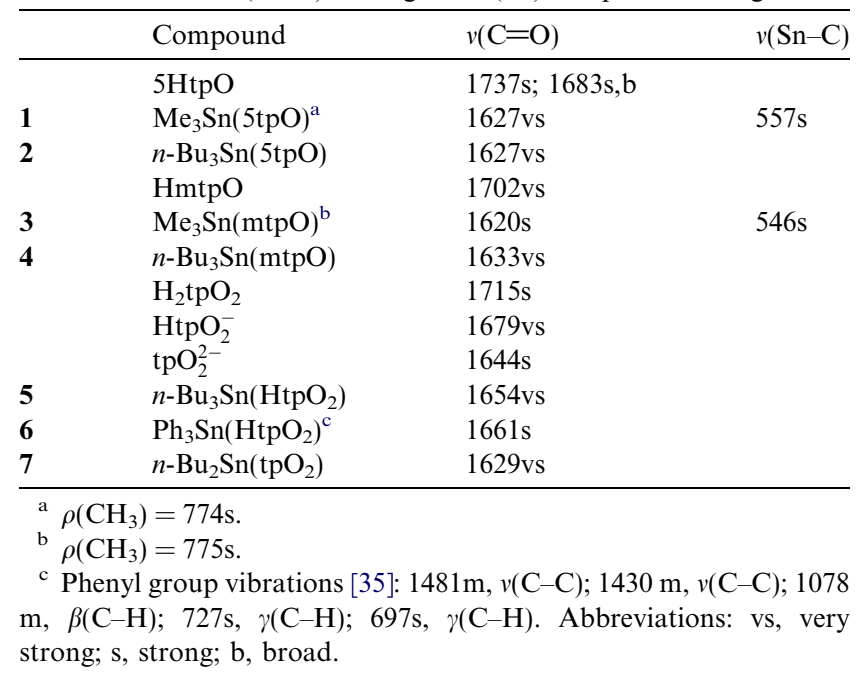

$\left[\mathrm{Ph}_{3} \mathrm{Sn}\left(\mathrm{HtpO}_{2}\right)\right](6): \mathrm{Ph}_{3} \mathrm{SnOH}+\mathrm{H}_{2} \mathrm{tpO}_{2}$ : the solution was refluxed for $2 \mathrm{~h}$, then concentrated in vacuo. A viscous product was obtained which gave a white solid product when dried under vacuum. m.p. $292{ }^{\circ} \mathrm{C}$ (dec). Anal. Calc. for $\mathrm{C}_{23} \mathrm{H}_{18} \mathrm{~N}_{4} \mathrm{O}_{2} \mathrm{Sn}\left(501.135 \mathrm{~g} \mathrm{~mol}^{-1}\right)$ C, 55.13; H, 3.62; N, 11.18. Found: C, 54.74; H, 3.79; N, $10.57 \%$.

$\left[n-\mathrm{Bu}_{2} \mathrm{Sn}\left(\mathrm{tpO}_{2}\right)_{2}\right](7)$ was obtained by refluxing a mixture of $\mathrm{H}_{2} \mathrm{tpO}_{2}$ and $n-\mathrm{Bu}_{2} \mathrm{SnO}$ (in both 1:1 and 2:1 ratios), or $n-\mathrm{Bu}_{2} \mathrm{Sn}(\mathrm{OMe})_{2}(1: 1$ ratio) for $3 \mathrm{~h}$. The solid white product was then filtered and dried in vacuo. m.p. $300{ }^{\circ} \mathrm{C}$ (dec). Anal. Calc. for $\mathrm{C}_{13} \mathrm{H}_{20} \mathrm{~N}_{4} \mathrm{O}_{2} \mathrm{Sn}$ (383.040 $\left.\mathrm{g} \mathrm{mol}^{-1}\right) \mathrm{C}, 40.77 ; \mathrm{H}, 5.26 ; \mathrm{N}, 14.63$. Found: C, $40.83 ; \mathrm{H}, 5.27 ; \mathrm{N}, 14.34 \%$.

\subsection{Antimicrobial activity}

\subsubsection{Microorganisms}

The microbial strains used were Escherichia coli ATCC 25922, Pseudomonas aeruginosa ATCC 9027,
Staphylococcus aureus ATCC 25923, Staphylococcus epidermidis DSM 3269, Candida albicans ATCC 10231 and Candida tropicalis ATCC 13803.

\subsubsection{Antibacterial activity}

2.3.2.1. Determination of the minimum inhibitory concentrations (MICs) by broth dilution micro-method. A series of solutions with a range of concentrations from 100 to $0.37 \mu \mathrm{g} / \mathrm{mL}$ (obtained by twofold serial dilution) was prepared. The serial dilutions were made in Mueller Hinton broth (Merck KGaA, Germany) in a 96-wells plate starting from a stock solution of 10 $\mathrm{mg} / \mathrm{mL}$ in ethanol. To each well $10 \mu \mathrm{L}$ of a bacterial suspension, obtained from a $24 \mathrm{~h}$ culture, containing $\sim 10^{6} \mathrm{cfu} / \mathrm{mL}$ was added [8]. The plate was incubated at $37{ }^{\circ} \mathrm{C}$ for $24 \mathrm{~h}$; after this time the MICs were determined, by a microplate reader (ELX 800, Bio-Tek Instruments), as the lowest concentration of the compound whose optical density, read at $570 \mathrm{~nm}$, was comparable to the negative control wells (broth only, without inoculum). For comparative purpose and quality control of the method we tested the antibiotic amikacin.

\subsubsection{Antifungal activity}

2.3.3.1. Determination of MICs by broth dilution. A series of solutions of each substance with a range of concentrations from 100 to $0.37 \mu \mathrm{g} / \mathrm{mL}$ (obtained by twofold serial dilution) was prepared in Sabouraud dextrose broth, using a stock solution of $10 \mathrm{mg} / \mathrm{mL}$ in ethanol. The test tubes were seeded using a fungal suspension containing $\sim 10^{5} \mathrm{cfu} / \mathrm{mL}$. The microbial cultures were incubated at $37^{\circ} \mathrm{C}$ for $24 \mathrm{~h}$. The lowest concentration of substance which completely inhibited the growth of the test organism when compared with the growth of a drug-free control, but added with maximum volume of solvent, was considered the MIC. Amphotericin B was used for comparative purpose and quality control of the method. 


\subsubsection{Inhibition of germ tube formation}

Sabouraud dextrose broth containing $20 \%$ foetal bovine serum was used as medium in germ tube formation assay. $1 \mathrm{~mL}$ of a fungal suspension in $0.9 \% \mathrm{NaCl}$, whose transmittance at $570 \mathrm{~nm}$ was about $15 \%$, was seeded in the medium described before, supplemented with several concentrations ranging from 3 to 0.78 $\mu \mathrm{g} / \mathrm{mL}$ of $n-\mathrm{Bu}_{3} \mathrm{Sn}\left(\mathrm{HtpO}_{2}\right)(\mathbf{5})$, its organotin precursor $n-\mathrm{Bu}_{3} \mathrm{SnOCH}_{3}$, and $\mathrm{Ph}_{3} \mathrm{Sn}\left(\mathrm{HtpO}_{2}\right)$ (6) (that showed the best activity on C. albicans) and incubated at 37 ${ }^{\circ} \mathrm{C}$ in shaking bath for $3 \mathrm{~h}$. After this incubation time we determined, by counting in a hematocytometer, the number of cells with germ tube and we could calculate the inhibition percentages by comparing the sample with a drug-free growth control, but added with maximum concentration of solvent used to dissolve the substances, undergone to the same experimental conditions.

\subsubsection{Biofilms susceptibility testing}

C. albicans ATCC 10231 was cultivated in yeast nitrogen base (YNB) medium (Sigma) with $50 \mathrm{mM}$ glucose at $37{ }^{\circ} \mathrm{C}$ for $24 \mathrm{~h}$. After this time it was diluted in the same medium to an optical density of 0.8 at 520 $\mathrm{nm}$. [9]. $100 \mu \mathrm{L}$ of such suspension were inoculated in wells of a 96-well plates at $37{ }^{\circ} \mathrm{C}$; after $24 \mathrm{~h}$ the wells were washed three times with $200 \mu \mathrm{L}$ of sterile phosphate-buffered saline (PBS). The plates were air dried at $37{ }^{\circ} \mathrm{C}$ and to each well, except in the case of positive (growth) controls, $100 \mu \mathrm{L}$ broth Sabouraud were added, supplemented with concentrations ranging from 25 to $0.78 \mu \mathrm{g} / \mathrm{mL}$, the MIC of $n-\mathrm{Bu}_{3} \mathrm{Sn}\left(\mathrm{HtpO}_{2}\right)$ determined on planktonic form of the same strain. The plates were incubated at $37{ }^{\circ} \mathrm{C}$ for $24 \mathrm{~h}$; after this incubation time the medium was removed, the plates were air dried and then each well was filled with $100 \mu \mathrm{L}$ of PBS adding $20 \mu \mathrm{L}$ of a $5 \mathrm{mg} / \mathrm{mL}$ MTT (methylthiazotetrazolium) solution and incubated for $4 \mathrm{~h}$ at $37^{\circ} \mathrm{C}$. The insoluble purple formazan, obtained by cleavage of MTT made by dehydrogenase enzymes of living cells, was dissolved with a mixture of acidic isopropyl alcohol and Triton X100 (Sigma). The optical density of each well was read by a microplate reader (ELX 800, Bio-Tek Instruments) at $570 \mathrm{~nm}$ with background subtraction at $630 \mathrm{~nm}$. Comparison of optical density of positive control wells with those of sample enabled the calculation of inhibition percentages of our substance at several concentrations.

Biological activity data are reported in Tables 7 and 8 and in Fig. 5.

\subsection{Quantum chemical calculations}

DFT calculations, with full geometry optimization, were performed on the 4,5,6,7-tetrahydro-5,7-dioxo$[1,2,4]$ triazolo-[1,5a]-pyrimidine $\left(\mathrm{H}_{2} \mathrm{tpO}_{2}\right)$ ligand, and on the two mono-anionic and on the di-anionic forms (see Fig. 3), by the hybrid B3LYP method and using the $6-31++G(D, P)$ basis set $[10]$. A vibration analysis was performed within the harmonic approximation, and the unscaled frequency values were compared with the corresponding experimental data. A two layers ONIOM calculation [11], with full geometry optimization, was performed on two isomeric trans-di- $n$-butyl octahedral model complexes of di- $n$-butyltin(IV) with the $\mathrm{tpO}_{2}^{2-}$ ligand, mimicking a truncated mono-dimensional polymer with cis- $\mathrm{O}_{2}$ and trans $-\mathrm{O}_{2}$ coordination, respectively (see Fig. 4). The DFT B3lyp level, with the DZVP basis set [12], was used for the higher layer, including the central di- $n$-butyltin moiety and the two coordinated $\mathrm{tpO}_{2}^{2-}$ ligands; the semiempirical AM1 method was used for the lower layer. To neutralize the overall charge of the system, the external ligands were considered monoanionic. All calculations were performed by the Gaussian98 program package [13]. The ${ }^{119} \mathrm{Sn}$ Mössbauer nuclear quadrupole splitting was calculated by the calibration formula $\Delta E_{\text {calcd }}=0.93 \cdot V \pm$ $0.58 \mathrm{~mm} \mathrm{~s}^{-1}[14]$, where $V=V_{z z}\left[1+\frac{1}{3}\left(\frac{V_{x x}-V_{y y}}{V_{z z}}\right)^{2}\right]^{1 / 2}$ and where $V_{x x}, V_{y y}, V_{z z}$, following the condition $\left|V_{z z}\right| \geqslant$ $\left|V_{y y}\right| \geqslant\left|V_{x x}\right|$, are the eigenvalues of the diagonalized electric field gradient tensor, calculated at the same level of theory of the higher layer [14].

\section{Results and discussion}

\subsection{HtpO derivatives}

The most basic positions for the ligand in the molecular or anionic form appear to be, on the basis of semiempirical [5] and ab initio calculations [15], N(3) and $\mathrm{N}(4)$, respectively (Fig. 1).

X-ray structures of some transition metal complexes show that in most cases the ligand, in his neutral enolic or anionic form, bridges two metal ions through $\mathrm{N}(3)$, $\mathrm{N}(4)$ atoms $[16,4,17]$; only two exceptions are known, $\left.\left[\mathrm{Cu}_{2} \text { (phen }\right)_{2}(5 \mathrm{tpO})_{2}\left(\mathrm{H}_{2} \mathrm{O}\right)_{2}\right]\left(\mathrm{NO}_{3}\right)_{2} \cdot 4 \mathrm{H}_{2} \mathrm{O} \quad[16]$ where 5 tpO ${ }^{-}$bridges two $\mathrm{Cu}^{2+}$ ions through $\mathrm{N}(3)$ and $\mathrm{O}(5)$ atoms, and $\left[\mathrm{Ni}(\mathrm{NCS})_{2}(5 \mathrm{HtpO})_{2} \cdot\left(\mathrm{H}_{2} \mathrm{O}\right)_{2}\right]$ [18], characterized by an all-trans octahedral structure with two $5 \mathrm{HtpO}$ ligands coordinated through the $\mathrm{N}$ atom in position 3. The ionization of the ligand is normally associated to a shift of the $v(\mathrm{C}=\mathrm{O})$ absorption to lower wavenumbers, while an extra-shift has been attributed to the involvement of $\mathrm{O}(5)$ in coordination [16]. In fact, in the above mentioned copper complex [16], where the triazolopyrimidine ligand binds the copper ions through $\mathrm{N}(3)$ and $\mathrm{O}(5), v(\mathrm{C}=\mathrm{O})$ is at $1637 \mathrm{~cm}^{-1}$, while in complexes where the ligand is $\mathrm{N}(3), \mathrm{N}(4)$ coordinated, $v(\mathrm{C}=\mathrm{O})$ appears near $1650 \mathrm{~cm}^{-1}[16]$.

In the $\mathrm{Me}_{3} \mathrm{Sn}(5 \mathrm{tpO})$ and $n-\mathrm{Bu}_{3} \mathrm{Sn}(5 \mathrm{tpO})$ complexes the $v(\mathrm{C}=\mathrm{O})$ absorption is observed at $1627 \mathrm{~cm}^{-1}$ 
strongly suggesting the involvement of the exocyclic oxygen in the bond (Table 3 ).

The ${ }^{119} \mathrm{Sn}$ Mössbauer quadrupole splitting values, reported in Table 1, allow us to make the following considerations about the coordination geometry of compounds 1 and 2: (i) tetrahedral species, originated by unidentate ligand coordination, can be excluded on the basis of the $\Delta E$ values, considerably larger than those observed for compounds of such geometry $(<3.2$ $\mathrm{mm} \mathrm{s}^{-1}$, [19]); (ii) the coordination number of tin may increase as a result of a bidentate, chelate or bridged bis-unidentate, coordination. Chelation through N(4), $\mathrm{O}(5)$ would be sterically favoured with respect to the N(3), N(4) one (see Fig. 1), consistently with the remarkable shift of the $v(\mathrm{C}=\mathrm{O})$ band. Two geometries would be in this case formally possible, i.e., fac $-\mathrm{R}_{3}$ and $m e r-\mathrm{R}_{3}$ trigonal bipyramidal; in both cases a severely distorted structure would be expected, due to the narrow bite angle in the ligand. Assuming regular structures, the $f a c-\mathrm{R}_{3}$ configuration may be excluded, as the quadrupole splitting value would be considerably lower than that observed, while it falls in the characteristic range for mer $-\mathrm{R}_{3}$ tbp complexes (2.99-4.08 $\mathrm{mm} \mathrm{s}^{-1}$ [19]). Actually, the distortions introduced by the $\mathrm{O} \cap \mathrm{N}$ (or, possibly, $\mathrm{N} \cap \mathrm{N}$ ) chelation would preferentially give rise to a distorted tetrahedron with a long, additional tin-ligand bond [20] and a considerably lower quadrupole splitting value [19].

As a result of the above considerations, the most reliable hypothesis is that the anionic ligand bridges two $\mathrm{R}_{3} \mathrm{Sn}^{\mathrm{IV}}$ units through $\mathrm{O}(5)$ and $\mathrm{N}(3)$ donor atoms. The observed quadrupole splitting values fully agree with such a structure. The geometry of the trimethyltin group may be deduced from the tin-carbon stretching modes which occur in the $550-500 \mathrm{~cm}^{-1}$ region of the infrared spectra. A trigonal-planar $\mathrm{SnC}_{3}$ structure (local $\mathrm{D}_{3 \mathrm{~h}}$ symmetry) will give rise to infrared-active $v_{\text {asym }}(\mathrm{Sn}-\mathrm{C})$ modes, but also the $v_{\text {sym }}(\mathrm{Sn}-\mathrm{C})$ mode will appear in the spectrum if there is significant deviation from planarity. In the infrared spectrum of $\mathrm{Me}_{3} \mathrm{Sn}(5 \mathrm{tpO})$ an intense absorption at $557 \mathrm{~cm}^{-1}$ can be attributed to $v_{\text {asym }}(\mathrm{Sn}-\mathrm{C})$; a much less intense band, at $514 \mathrm{~cm}^{-1}$, is difficult to be attributed owing to the presence of many ligand absorptions, while a $\rho\left(\mathrm{CH}_{3}\right)$ intense band is present at $774 \mathrm{~cm}^{-1}$. Hence, the infrared spectra support the hypothesis of the $\mathrm{R}_{3} \mathrm{Sn}$ group being planar or nearly planar in the proposed structure shown in Fig. 2.

\subsection{HmtpO derivatives}

The literature data relative to transition metal complexes of HmtpO show a strong preference for the $\mathrm{N}(3)$ coordination [21]. When the ligand is in the anionic form, also a $\mathrm{N}(3), \mathrm{N}(4)$ bridging coordination is observed in dinuclear [22-25] or polynuclear complexes [25]. Only in one case $\left(\left[\mathrm{Cu}(\mathrm{mtpO})_{2}(1,3\right.\right.$-propane di-

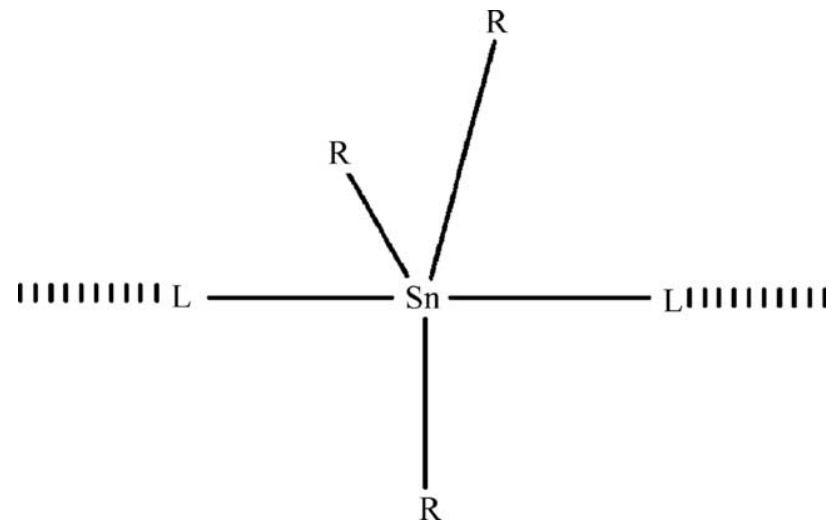

Fig. 2. Proposed structure for $\mathrm{R}_{3} \mathrm{SnL}\left(\mathrm{R}=\mathrm{Me}, n-\mathrm{Bu}, \mathrm{L}=5 \mathrm{tpO}^{-}\right.$; $\mathrm{R}=\mathrm{Me}, \mathrm{L}=\mathrm{mtpO}^{-} ; \mathrm{R}=n-\mathrm{Bu}, \mathrm{Ph}, \mathrm{L}=\mathrm{HtpO}_{2}^{-}$.

amine)] $2 \mathrm{H}_{2} \mathrm{O},[21]$ ) a $\mathrm{N}(1), \mathrm{O}(7)$ chelation by $\mathrm{mtpO} \mathrm{O}^{-}$ was reported while an $\mathrm{O}(7)-$ metal ion interaction was observed in the complexes $\mathrm{Ag}\left(\mathrm{NO}_{3}\right)(\mathrm{HmtpO})(\mathrm{O}(7)-$ $\mathrm{Ag}=2.69 \AA)$ [25], $\mathrm{Ag}_{3}\left(\mathrm{HSO}_{4}\right)(\mathrm{mtpO})_{2} \cdot 3 \mathrm{H}_{2} \mathrm{O} \quad(\mathrm{O}(7)-$ $\mathrm{Ag}=2.63 \AA)[25]$ and $\mathrm{Ag}(\mathrm{mtpO})(\mathrm{O}(7)-\mathrm{Ag}=2.78 \AA)$ [26]. The infrared spectra of the complexes with the molecular form of the ligand (HmtpO), are generally characterized by a $\sim 20 \mathrm{~cm}^{-1}$ shift to high frequency $[27,21,28]$, but minimal changes were observed in some cases, including the chelate complex $\mathrm{Ag}\left(\mathrm{NO}_{3}\right)(\mathrm{HmtpO})$ $[25,29]$, or a consistent shift to lower frequency $[30,27]$. On the other hand, a $30-60 \mathrm{~cm}^{-1}$ shift to low frequency seems to be associated to the deprotonation of HmtpO $[21,30]$. The sole exception is the above mentioned copper complex [21], whose infrared spectrum is characterized by a very small shift of the $v(\mathrm{C}=\mathrm{O})$ band, from 1700 to $1695 \mathrm{~cm}^{-1}$.

The complexes $\mathrm{Me}_{3} \mathrm{Sn}(\mathrm{mtpO})(3)$ and $n-\mathrm{Bu}_{3} \mathrm{Sn}(\mathrm{mtpO})$ (4) were obtained neutralizing the triorganotin(IV) hydroxides with HmtpO and contain the ligand in the deprotonated form. Their infrared spectra (Table 3 ) show the expected shift to low frequency of the $v(\mathrm{C}=\mathrm{O})$ absorption band, associated with the ionization of the ligand: $v(\mathrm{C}=\mathrm{O})=1702,1620$ and $1633 \mathrm{~cm}^{-1}$ for HmtpO, $\mathrm{Me}_{3} \mathrm{Sn}(\mathrm{mtpO})$ and $n-\mathrm{Bu}_{3} \mathrm{Sn}(\mathrm{mtpO})$, respectively.

In the spectrum of $\mathrm{Me}_{3} \mathrm{Sn}(\mathrm{mtpO})$ an intense absorption at $546 \mathrm{~cm}^{-1}$ may be attributed to the asymmetric tin-carbon stretching, while no absorptions are present which may be attributed to $v_{\mathrm{sym}}(\mathrm{Sn}-\mathrm{C})$. That is consistent with the presence of planar $\mathrm{SnC}_{3}$ groups bridged by bis-monodentate $\mathrm{mtpO}^{-}$units. Mössbauer data (Table 1) support such hypothesis, the quadrupole splitting values being fully consistent with a trigonal bipyramidal structure (Fig. 2) with organic groups in the equatorial plane and electronegative groups in axial position. Donor atoms would be $\mathrm{N}(3)$ and $\mathrm{N}(1)$, as in $\left\{\mathrm{Ag}\left(\mathrm{NO}_{3}\right)\left(\mu-\mathrm{HmtpO}-\kappa^{2} \mathrm{~N}^{1}, \mathrm{~N}^{3}\right)\right\}_{n}[25]$. No evidence of a possible $\mathrm{Sn}-\mathrm{O}(7)$ interaction can be extracted from the infrared spectra. A $\rho\left(\mathrm{CH}_{3}\right)$ intense band is present at $775 \mathrm{~cm}^{-1}$ in the infrared spectrum of $\mathrm{Me}_{3} \mathrm{Sn}(\mathrm{mtpO})$. 


\section{3. $\mathrm{H}_{2} \mathrm{tp} \mathrm{O}_{2}$ derivatives}

The most stable tautomers of the ligand in the molecular form $\left(\mathrm{H}_{2} \mathrm{tpO}_{2}\right)$ and in its monoanionic $\left(\mathrm{HtpO}_{2}^{-}\right)$ and dianionic form $\left(\mathrm{tpO}_{2}^{2-}\right)$, as derived from theoretical calculations [6, this work] are shown in Fig. 3. The first ionization of the ligand involves the strongly acidic $\mathrm{C}(6)$ methylene group $\left(\mathrm{p} K_{\mathrm{a} 1}=2.9\right)$ [6], while the second ionization ( $\left.\mathrm{p} K_{\mathrm{a} 2}=9.9\right)$ concerns the $\mathrm{N}(4)$ hydrogen [6].

The infrared spectra of the ligand (Table 3 ) are characterized by a strong, broad absorption due to stretching vibrations of both the carbonyl groups, centred at 1715,1679 and $1644 \mathrm{~cm}^{-1}$ in the spectra of $\mathrm{H}_{2} \mathrm{tpO}_{2}$, $\mathrm{NaHtpO}$ and $\mathrm{Na}_{2} \mathrm{tpO}_{2}$, respectively.

The greater stability of the $\mathrm{C}(6)$ compared to the $\mathrm{N}(4)$ first deprotonation was confirmed by our DFT calculations, showing that the $\mathrm{HtpO}_{2}^{-}$isomer $\mathrm{A}$ is more stable, of $31.9 \mathrm{~kJ} / \mathrm{mol}$, than $\mathrm{HtpO}_{2}^{-}$- B (see Fig. 3).

While the neutral and monoanionic form of the $\mathrm{H}_{2} \mathrm{tpO}_{2}$ ligand have been previously characterized both experimentally and by semi-empirical quantum chemical calculations [6], the structure of the dianionic form has not been up to date considered. Quite obviously, the ring planarity is preserved in all the systems investigated. The enolic character, hence the coordination strength toward hard metals, of the oxygen hetero-atoms increases by increasing the negative charge of the molecule. This can be observed in Table 4, by considering the increasing trend in the $\mathrm{C}-\mathrm{O}$ bond length (of about $0.06 \AA$ ) and, qualitatively, in the Mulliken negative charge on the oxygen atoms, by going from $\mathrm{H}_{2} \mathrm{tpO}_{2}$ to
$\mathrm{tpO}_{2}^{2-}$. This result is also supported by the monotonous lowering of the calculated IR frequency of the stretching bands of the carbonyl groups (see Table 5), in agreement with the experimental IR data relative to $\mathrm{NaHtpO}_{2}$, $\mathrm{Na}_{2} \mathrm{tpO}_{2}$ and $n-\mathrm{Bu}_{2} \mathrm{Sn}\left(\mathrm{tpO}_{2}\right)$, compared to the isolated ligand (see Table 3). Following the results of our calculations, this trend is to be attributable mainly to the increasing of the enolic character of the carbonyl groups following the deprotonations of the hydrogen atoms, respectively, on $\mathrm{C}(6)$ and $\mathrm{N}(4)$.

A previous theoretical study [6] showed that the exocyclic oxygens, $\mathrm{O}(7)$ and $\mathrm{O}(5)$, are the primary coordination sites for $\mathrm{HtpO}_{2}^{-}$. The $\mathrm{O}(7), \mathrm{N}(1)$ bidentate coordination, supported by the formation of a five membered chelate ring, is, however, preferred to other possible coordination modes.

The $\mathrm{O}(7), \mathrm{N}(1)$ coordination mode was observed in $\left[\mathrm{Mn}\left(\mathrm{HtpO}_{2}\right)_{2}\left(\mathrm{H}_{2} \mathrm{O}\right)_{2}\right][31]$ where the ligand has a geometry virtually identical to the one present in its sodium salt. Its infrared spectrum is characterized by the presence of the carbonyl group stretching band at 1652 $\mathrm{cm}^{-1}$. Comparing this value with that observed for $\mathrm{NaHtpO}_{2}$, the $v(\mathrm{C}=\mathrm{O})$ shift seems rather to be determined by the ionization of the ligand, than by metal coordination.

Triorganotin complexes, $n-\mathrm{Bu}_{3} \mathrm{Sn}\left(\mathrm{HtpO}_{2}\right)$ (5) and $\mathrm{Ph}_{3} \mathrm{Sn}\left(\mathrm{HtpO}_{2}\right)(6)$, exhibit similar infrared spectra, with the $v(\mathrm{C}=\mathrm{O})$ band centred at 1654 and $1661 \mathrm{~cm}^{-1}$, respectively. $\mathrm{O}(7), \mathrm{N}(1)$ bidentate coordination can be, however, ruled out on the basis of the ${ }^{119} \mathrm{Sn}$ Mössbauer quadrupole splitting values, which strongly suggest
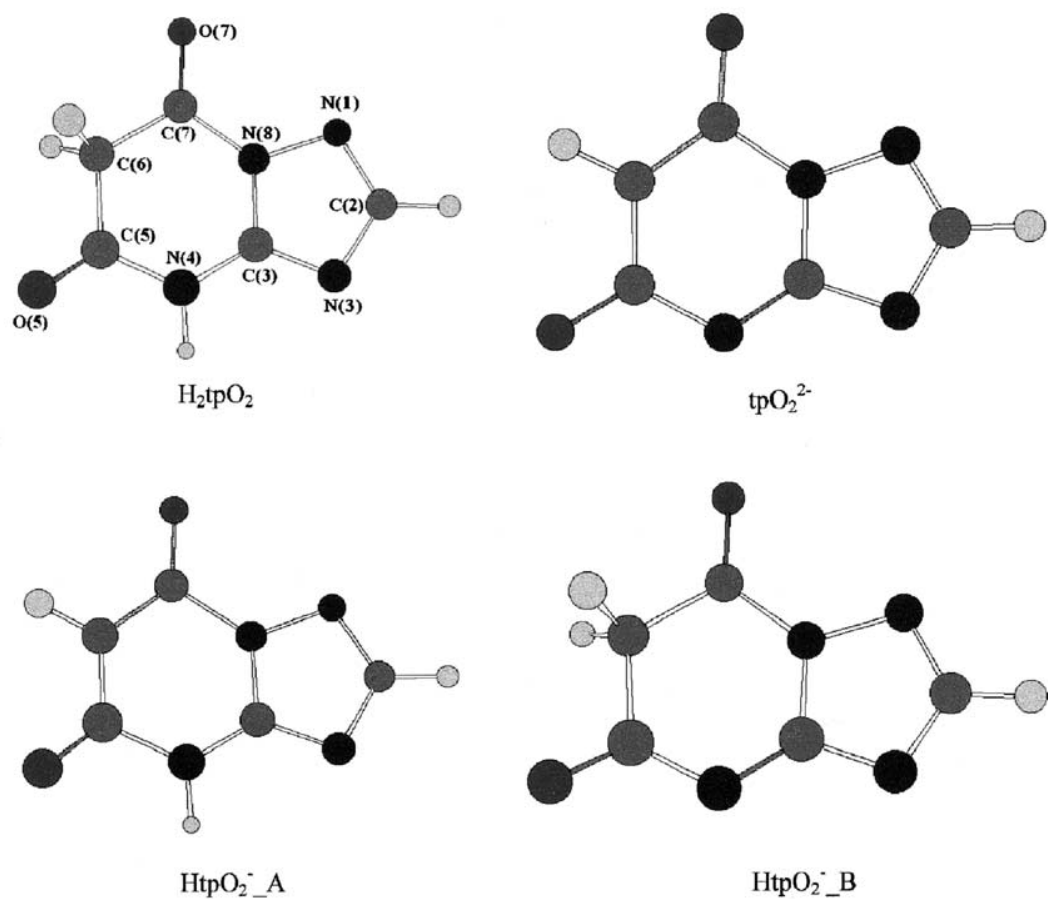

Fig. 3. Structures of the neutral, mono- and di-anionic $\mathrm{H}_{2} \mathrm{tpO}_{2}$ ligand, obtained after full geometry optimization at DFT level (see text). 
Table 4

Geometrical parameters (bond distances, in $\AA$, and angles, in ${ }^{\circ}$ ) and Mulliken charges $(Q)$ (in a.u.) on selected atoms, calculated at DFT level (see text) for the compounds shown in Fig. 3

\begin{tabular}{lrccr}
\hline & $\mathrm{H}_{2} \mathrm{tpO}_{2}$ & $\mathrm{HtpO}_{2}^{-}-\mathrm{A}$ & $\mathrm{HtpO}_{2}^{-}-\mathrm{B}$ & \multicolumn{1}{c}{$\mathrm{tpO}_{2}^{2-}$} \\
\hline $\mathrm{N}(1)-\mathrm{C}(2)$ & 1.313 & 1.321 & 1.319 & 1.329 \\
$\mathrm{C}(2)-\mathrm{N}(3)$ & 1.381 & 1.369 & 1.361 & 1.352 \\
$\mathrm{~N}(3)-\mathrm{C}(3)$ & 1.309 & 1.333 & 1.342 & 1.372 \\
$\mathrm{C}(3)-\mathrm{N}(8)$ & 1.375 & 1.360 & 1.421 & 1.396 \\
$\mathrm{C}(3)-\mathrm{N}(4)$ & 1.373 & 1.358 & 1.334 & 1.329 \\
$\mathrm{~N}(4)-\mathrm{C}(5)$ & 1.387 & 1.428 & 1.355 & 1.391 \\
$\mathrm{C}(5)-\mathrm{O}(5)$ & 1.216 & 1.248 & 1.241 & 1.274 \\
$\mathrm{C}(5)-\mathrm{C}(6)$ & 1.526 & 1.420 & 1.549 & 1.449 \\
$\mathrm{C}(6)-\mathrm{C}(7)$ & 1.526 & 1.418 & 1.518 & 1.409 \\
$\mathrm{C}(7)-\mathrm{O}(7)$ & 1.206 & 1.235 & 1.223 & 1.262 \\
$\mathrm{C}(7)-\mathrm{N}(8)$ & 1.409 & 1.462 & 1.380 & 1.432 \\
$\mathrm{~N}(1)-\mathrm{N}(8)$ & 1.381 & 1.375 & 1.389 & 1.383 \\
$\mathrm{~N}(1)-\mathrm{C}(2)-\mathrm{N}(3)$ & 116.4 & 116.7 & 118.1 & 118.0 \\
$\mathrm{C}(2)-\mathrm{N}(3)-\mathrm{C}(3)$ & 101.9 & 101.2 & 103.7 & 102.8 \\
$\mathrm{~N}(3)-\mathrm{C}(3)-\mathrm{N}(8)$ & 111.2 & 111.3 & 107.2 & 107.6 \\
$\mathrm{C}(3)-\mathrm{N}(4)-\mathrm{C}(5)$ & 123.7 & 122.8 & 118.1 & 116.8 \\
$\mathrm{~N}(4)-\mathrm{C}(5)-\mathrm{C}(6)$ & 116.1 & 115.1 & 120.2 & 119.2 \\
$\mathrm{C}(5)-\mathrm{C}(6)-\mathrm{C}(7)$ & 120.2 & 125.9 & 119.4 & 125.1 \\
$\mathrm{C}(6)-\mathrm{C}(7)-\mathrm{N}(8)$ & 113.3 & 112.0 & 112.2 & 111.0 \\
$\mathrm{C}(7)-\mathrm{N}(8)-\mathrm{C}(3)$ & 125.7 & 124.5 & 124.5 & 122.9 \\
$\mathrm{C}(3)-\mathrm{N}(8)-\mathrm{N}(1)$ & 108.6 & 108.9 & 110.2 & 110.7 \\
$\mathrm{~N}(8)-\mathrm{N}(1)-\mathrm{C}(2)$ & 101.9 & 101.9 & 100.8 & 100.9 \\
$Q_{\mathrm{N}(1)}$ & -0.21 & -0.36 & -0.32 & -0.42 \\
$Q_{\mathrm{N}(3)}$ & -0.33 & -0.40 & -0.36 & -0.39 \\
$Q_{\mathrm{N}(4)}$ & -0.46 & -0.54 & -0.49 & -0.55 \\
$Q_{\mathrm{O}(5)}$ & -0.44 & -0.63 & -0.54 & -0.69 \\
$Q_{\mathrm{O}(7)}$ & -0.40 & -0.59 & -0.50 & -0.70 \\
$Q_{\mathrm{N}(8)}$ & -0.11 & -0.11 & -0.08 & -0.09 \\
\hline & & & &
\end{tabular}

Table 5

IR carbonyl bands $\left(\mathrm{cm}^{-1}\right)$ calculated for the neutral, mono- and dianionic $\mathrm{H}_{2} \mathrm{tpO}_{2}$ ligand

\begin{tabular}{lll}
\hline & $v(\mathrm{C}(7) \mathrm{O}(7))$ & $v(\mathrm{C}(5) \mathrm{O}(5))$ \\
\hline $\mathrm{H}_{2} \mathrm{tpO}_{2}$ & 1837 & 1796 \\
$\mathrm{HtpO}_{2}^{-}-\mathrm{A}$ & 1730 & 1693 \\
$\operatorname{tpO}_{2}^{2-}$ & 1651 & 1557 \\
& & 1546 \\
\hline
\end{tabular}

trigonal bipyramidal structures with organic groups in equatorial position. In particular, the Mössbauer parameters of $n-\mathrm{Bu}_{3} \mathrm{Sn}\left(\mathrm{HtpO}_{2}\right) \quad(\delta=1.48 ; \Delta E=3.90$ $\left.\mathrm{mm} \mathrm{s}^{-1}\right)$ are very similar to those of tri- $n$-butyltin 2 [(E)-2-(2-hydroxy-5-methylphenyl)-1-diazenyl]benzoate [32] $\left(\delta=1.50 ; \Delta E=3.85 \mathrm{~mm} \mathrm{~s}^{-1}\right)$, characterized by a distorted trigonal bipyramidal trans $-\mathrm{R}_{3} \mathrm{SnO}_{2}$ geometry with non-equivalent $\mathrm{Sn}-\mathrm{O}$ bonds. Taking into account the different electron donor character of alkyl- and aryl-groups, the complexes $n-\mathrm{Bu}_{3} \mathrm{Sn}\left(\mathrm{HtpO}_{2}\right)$ and $\mathrm{Ph}_{3} \mathrm{Sn}\left(\mathrm{HtpO}_{2}\right)$ appear to be isostructural on the base of the Mössbauer parameters. According to the base character of the ligand donor atoms we can reasonably hypothesize a trans $-\mathrm{O}_{2} \mathrm{R}_{3} \mathrm{SnO}_{2}$ structure for our complexes, $\mathrm{HtpO}_{2}^{-}$bridging tin centres through $\mathrm{O}(7)$ and $\mathrm{O}(5)$ (see Fig. 2). Calculations of quadrupole splittings based on the point-charge formalism [33], attributing to the ligand a pqs $=0.13 \mathrm{~mm} \mathrm{~s}^{-1}$, derived by Bancroft [34] for O-coordinated dimethylformamide, give $\mathrm{QS}_{\text {calc }}$ values of $3.91 \mathrm{~mm} \mathrm{~s}^{-1}$ for $\mathrm{Al} \kappa_{3} \mathrm{Sn}\left(\mathrm{HtpO}_{2}\right)$ and of 3.46 $\mathrm{mm} \mathrm{s}^{-1}$ for $\mathrm{Ph}_{3} \mathrm{Sn}\left(\mathrm{HtpO}_{2}\right)$, which agree with the experimental data (see Table 1). It is worth to note that the $\mathrm{O}(7)-\mathrm{N}(1)$ chelation would give a $f a c-\mathrm{R}_{3}$ trigonal bipyramidal structure with a remarkably lower quadruple splitting. On the other hand, the polymeric nature of the products is supported by the circumstance that $\mathrm{Ph}_{3} \mathrm{Sn}\left(\mathrm{HtpO}_{2}\right)$ exhibits an observable Mössbauer spectrum at room temperature.

Further evidences would in principle be deduced from the infrared spectra, on the basis, e.g., of tin-carbon stretching frequencies; unfortunately, due to the presence of many bands, it is not possible to assign with certainty the absorptions relative to tin-ligand vibrations. However, in the spectrum of the triphenyltin(IV) derivative 6, following Kriegsmann and Geissler [35], we can attribute to phenyl group vibrations the bands at $1481 \mathrm{~m}$ and $1430 \mathrm{~m}(v(\mathrm{C}-\mathrm{C}))$, at $1078 \mathrm{~m}(\beta(\mathrm{C}-\mathrm{H}))$, at $727 \mathrm{~s}$ and 697s $(\gamma(\mathrm{C}-\mathrm{H}))[35]$.

Our structural hypotheses seem probable on the basis of the nature of the ligand and the chemistry of triorganotins and is fully supported by Mössbauer data.

The triorganotin derivatives $\mathbf{5}$ and $\mathbf{6}$, selected for the biological tests (see Section 3.4, antimicrobial activity) were also characterized in solution phase by means of ${ }^{13} \mathrm{C}$ NMR and ${ }^{119} \mathrm{Sn}$ Mössbauer spectroscopy. Owing to the low solubility in water, methanol solutions were employed; the tributyltin derivative, being considerably soluble, produced good NMR and Mössbauer spectra, while only satisfactory Mössbauer spectra (on the frozen saturated solution) were obtained for $\mathrm{Ph}_{3} \mathrm{Sn}\left(\mathrm{HtpO}_{2}\right)$. The scarce solubility of $\mathbf{6}$ obviously didn't affect the biological assays, very little amounts of drug being requested (see experimental section). The spectral data in solution phase are reported in Table 2. The ${ }^{13} \mathrm{C}$ NMR spectrum of $n-\mathrm{Bu}_{3} \mathrm{Sn}\left(\mathrm{HtpO}_{2}\right)$ confirms the composition of the complex, and the value of the coupling constant $\left|{ }^{1} J\left({ }^{13} \mathrm{C}-{ }^{119} \mathrm{Sn}\right)\right|, 454.5 \mathrm{~Hz}$, indicates that the $\mathrm{C}_{3} \mathrm{Sn}$ unit maintains in methanol solution the same geometry assumed by the complex in the solid state, the C-Sn-C angle being $120^{\circ}$ [36]. The same conclusion may be extracted, on the other hand, from the Mössbauer spectrum on the frozen solution, the hyperfine parameters being fully consistent with those relative to the solid state complex (see Tables 1 and 2). The Mössbauer data show also that the triphenyltin derivative maintains the trigonal bipyramidal structure in methanol solution. In order to evaluate if the complex is stable in aqueous solution, the Mössbauer spectrum of a frozen methanol/aqueous solution (2:1) of $\mathbf{5}$ was measured; as shown in Table 2, the Mössbauer parameters still fully agree with those relative to the solid state complex. We can conclude that the complexes tested for biological activity 
maintain in solution the same structure they have in the solid state.

The diorganotin derivative, $n-\mathrm{Bu}_{2} \mathrm{Sn}\left(\mathrm{tpO}_{2}\right)$ (7) was obtained reacting $n-\mathrm{Bu}_{2} \mathrm{SnO}$ with $\mathrm{H}_{2} \mathrm{tpO}_{2}$ (in $1: 1$ and 1:2 ratios), or $n-\mathrm{Bu}_{2} \mathrm{Sn}(\mathrm{OMe})_{2}$ with $\mathrm{H}_{2} \mathrm{tpO}_{2}$ (1:1 ratio). In any case a compound is obtained whose Mössbauer spectrum is characterized by a very wide doublet $(\Delta E$ mean $=4.44 \mathrm{~mm} \mathrm{~s}^{-1} ; \Gamma_{\text {mean }}=0.91 \mathrm{~mm} \mathrm{~s}^{-1}$ ) typical of trans $-\mathrm{R}_{2}$ octahedral structures. The complex exhibits observable Mössbauer spectrum at room temperature suggesting a polymeric nature. On the other hand, considering the stoichiometry of the compound, only a polymeric structure would justify the observed nuclear quadrupole splitting, as only a bridged coordination of the ligand would allow an octahedral arrangement of ligand atoms around tin.

A trans $-\mathrm{R}_{2}$ octahedral structure implies that the ligand chelates two organotin(IV) moieties. A donor atoms couple would be obviously $\mathrm{O}(7)-\mathrm{N}(1)$, while the other one could be either $\mathrm{O}(5)-\mathrm{N}(4)$ or $\mathrm{N}(4)-\mathrm{N}(3)$. Moreover, there is a consequent ambiguity about the mutual disposition of the chelating ligands in the equa- torial plane. The infrared spectrum of the complex show a strong, broad band centred at $1629 \mathrm{~cm}^{-1}$ (see Table 3) attributable to carbonyl stretching frequencies. The observed shift is consistent with the presence of the dianionic form of the ligand, $\mathrm{tpO}_{2}^{2-}$.

With the aim to explain the experimental results in terms of structural properties of this complex, quantum chemical calculations by the ONIOM method have been performed on two model systems of the polymeric $n-\mathrm{Bu}_{2} \mathrm{Sn}\left(\mathrm{tpO}_{2}\right)$ complex, shown in Fig. 4. The two isomeric trans- $n-\mathrm{Bu}_{2}$ octahedral structures, $n-\mathrm{Bu}_{2} \mathrm{Sn}$ $\left(\mathrm{tpO}_{2}\right) \_\mathrm{A}$ and $n-\mathrm{Bu}_{2} \mathrm{Sn}\left(\mathrm{tpO}_{2}\right) \_\mathrm{B}$ in Fig. 4 , involve the $\mathrm{N}(1), \mathrm{O}(7)$ and $\mathrm{N}(4), \mathrm{O}(5)$ bis-chelate coordination, with, respectively, cis- $\mathrm{O}_{2}$ and trans $-\mathrm{O}_{2}$ disposition of the equatorial ligands.

Preliminary DFT calculations performed on the $n-\mathrm{Bu}_{2} \mathrm{Sn}\left(\mathrm{tpO}_{2}\right)_{2}^{2-}$ anion allowed us to rule out the possible chelating coordination through the atoms $\mathrm{N}(4)$, $\mathrm{N}(3)$. In fact, the two corresponding structures were more than $60 \mathrm{~kJ} / \mathrm{mol}$ less stable than the structure of lowest energy minimum found, i.e., the one with the coordination observed for $n-\mathrm{Bu}_{2} \mathrm{Sn}\left(\mathrm{tpO}_{2}\right) \_$A.
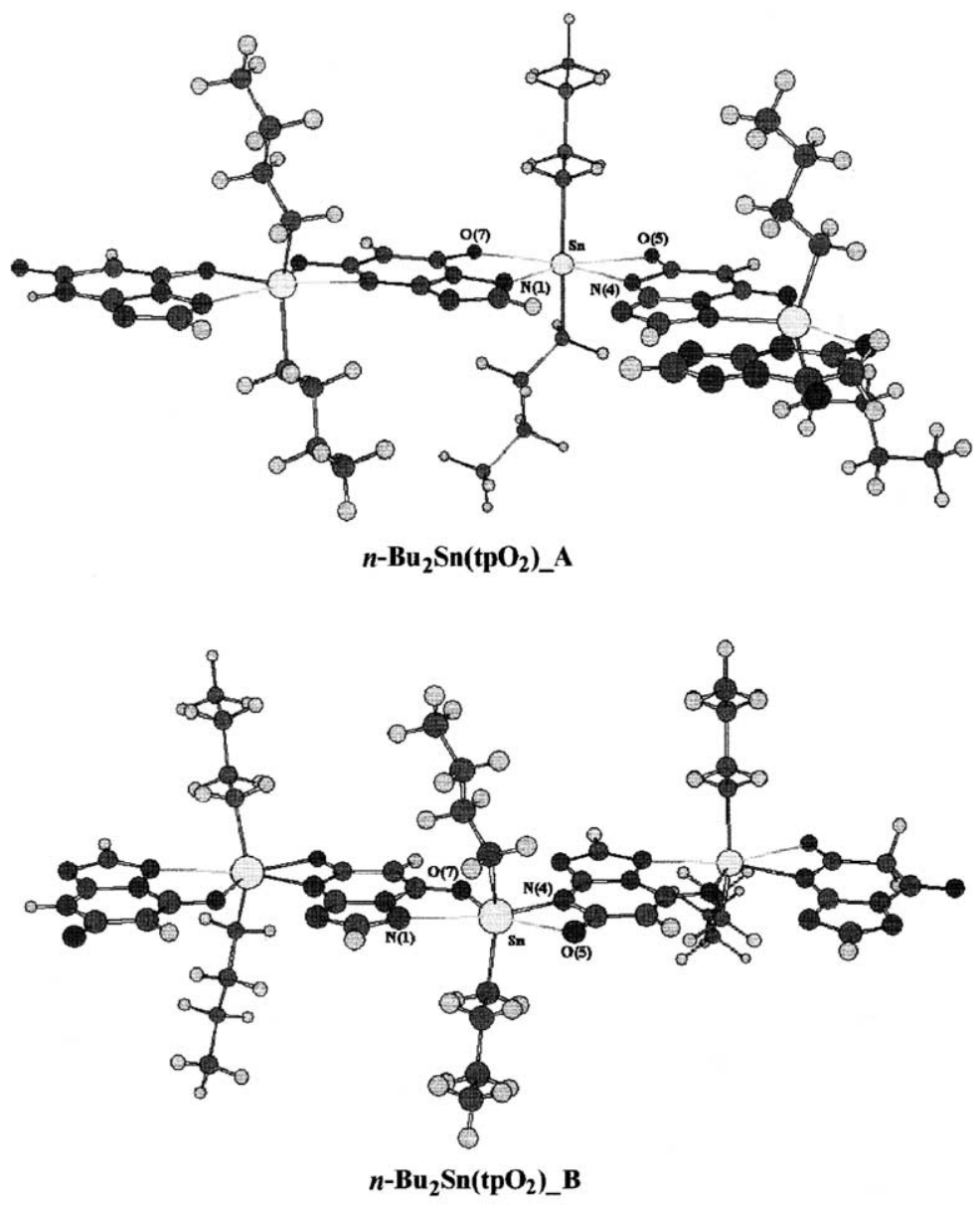

Fig. 4. Calculated structures, by a two layers ONIOM method (see text), of two isomeric model systems of the trans-dibutyl octahedral complex of the dibutyltin(IV) with $\mathrm{tpO}_{2}^{2-}, n-\mathrm{Bu}_{2} \mathrm{Sn}\left(\mathrm{tpO}_{2}\right) \_\mathrm{A}$ and $n-\mathrm{Bu}_{2} \mathrm{Sn}\left(\mathrm{tpO}_{2}\right) \_\mathrm{B}$, showing $c i s-\mathrm{O}_{2}$ and trans- $\mathrm{O}_{2}$ coordination, respectively. 
Among the two possible isomeric structures considered (see Fig. 4), the $c i s-\mathrm{O}_{2}$ coordination, corresponding to $n-\mathrm{Bu}_{2} \mathrm{Sn}\left(\mathrm{tpO}_{2}\right) \_\mathrm{A}$, is more stable of about $18 \mathrm{~kJ} / \mathrm{mol}$ compared to the trans $-\mathrm{O}_{2}$ coordination, corresponding to $n-\mathrm{Bu}_{2} \mathrm{Sn}\left(\mathrm{tpO}_{2}\right)$ B. Moreover, the calculated nuclear quadrupole splitting value relative to $n-\mathrm{Bu}_{2} \mathrm{Sn}\left(\mathrm{tpO}_{2}\right)_{-} \mathrm{A}$ is in much better agreement with the experimental value of $\Delta E$, compared to the one calculated for $n$ - $\mathrm{Bu}_{2} \mathrm{Sn}$ $(\mathrm{tpO})_{2} \_\mathrm{B}$ (see Table 6). These results strongly support the hypothesis of trans-di-n-butyl, cis- $\mathrm{O}_{2}$ distorted octahedral coordination geometry for the investigated compound.

A further support to such coordination geometry also comes from the polymeric structure obtained in the solid state for the complex $\mathrm{NaHtpO}_{2}$ [6]. The X-ray crystallographic analysis showed the involvement of a similar coordination of the metal atom through $\mathrm{N}(1), \mathrm{O}(7)$, $\mathrm{O}(5)$ and of the protonated $\mathrm{N}(4)$ atom through hydrogen bond to a coordinated water molecule. It is probable that the hard character of sodium and tin(IV) leads to the preferential coordination of the highly negatively charged oxygen atoms compared to the $\mathrm{N}(3)$ atom.

Table 6

Relevant geometrical parameters (bond distances, in $\AA$, and angles, in ${ }^{\circ}$ ) relative to the central tin environment of the two isomer model systems, $n-\mathrm{Bu}_{2} \mathrm{Sn}\left(\mathrm{tpO}_{2}\right) \_\mathrm{A}$ and $n-\mathrm{Bu}_{2} \mathrm{Sn}\left(\mathrm{tpO}_{2}\right) \_\mathrm{B}$, shown in Fig. 4, calculated by a two layer ONIOM method (see text). Their relative energy and the calculated nuclear quadrupole splitting values are also reported

\begin{tabular}{lcc}
\hline & $n-\mathrm{Bu}_{2} \mathrm{Sn}\left(\mathrm{tpO}_{2}\right) \_\mathrm{A}$ & $n-\mathrm{Bu}_{2} \mathrm{Sn}\left(\mathrm{tpO}_{2}\right) \_\mathrm{B}$ \\
\hline $\mathrm{Sn}-\mathrm{C}($ average $)$ & 2.175 & 2.173 \\
$\mathrm{Sn}-\mathrm{N}(1)$ & 2.299 & 2.701 \\
$\mathrm{Sn}-\mathrm{O}(7)$ & 2.411 & 2.161 \\
$\mathrm{Sn}-\mathrm{N}(4)$ & 2.325 & 2.249 \\
$\mathrm{Sn}-\mathrm{O}(5)$ & 2.412 & 2.412 \\
$\mathrm{C}(5)-\mathrm{O}(5)$ & 1.271 & 1.289 \\
$\mathrm{C}(7)-\mathrm{O}(7)$ & 1.269 & 1.273 \\
$\mathrm{C}-\mathrm{Sn}-\mathrm{C}$ & 150.7 & 142.8 \\
$\mathrm{~N}(1)-\mathrm{Sn}-\mathrm{O}(7)$ & 71.4 & 68.7 \\
$\mathrm{~N}(1)-\mathrm{Sn}-\mathrm{O}(5)$ & 147.3 & 150.7 \\
$\mathrm{~N}(1)-\mathrm{Sn}-\mathrm{N}(4)$ & 90.9 & 152.2 \\
$\mathrm{~N}(4)-\mathrm{Sn}-\mathrm{O}(5)$ & 56.5 & 57.1 \\
$\mathrm{~N}(4)-\mathrm{Sn}-\mathrm{O}(7)$ & 162.2 & 83.5 \\
$\mathrm{O}(5)-\mathrm{Sn}-\mathrm{O}(7)$ & 141.3 & 140.4 \\
Energy $(\mathrm{kJ} / \mathrm{mol})$ & 0.0 & 18.5 \\
$\Delta E_{\text {calcd }}\left(\mathrm{mm} \mathrm{s}{ }^{-1}\right)$ & 4.15 & 3.78 \\
\hline
\end{tabular}

\subsection{Antimicrobial activity}

$n-\mathrm{Bu}_{3} \mathrm{Sn}\left(\mathrm{HtpO}_{2}\right)$ and $\mathrm{Ph}_{3} \mathrm{Sn}\left(\mathrm{HtpO}_{2}\right), \mathbf{5}$ and $\mathbf{6}$, and their organotin precursors $n-\mathrm{Bu}_{3} \mathrm{SnOCH}_{3}$ and $\mathrm{Ph}_{3} \mathrm{SnOH}$, were screened for their in vitro antimicrobial activity on a group of representative Gram-positive, Gram-negative bacteria and on two human pathogen fungal strains. The antimicrobial activities of the substances, expressed as minimum inhibitory concentration, are reported in Table 7.

A good activity (MIC equal to $3.1 \mu \mathrm{g} / \mathrm{mL}$ ) against $S$. epidermidis is exhibited by $\mathbf{5}$ better than the parent organotin(IV) compound, $n-\mathrm{Bu}_{3} \mathrm{SnOCH}_{3}$.

6 possessed a good activity as anti Gram positive while its parent $\mathrm{Ph}_{3} \mathrm{SnOH}$ resulted inactive at the maximum tested concentration. We also observed a good antifungal activity for $\mathbf{6}$, with MIC values of 0.78 against both strains of $C$. albicans and $C$. tropicalis.

A good antifungal activity was also shown by $n$ $\mathrm{Bu}_{3} \mathrm{Sn}\left(\mathrm{HtpO}_{2}\right)(5)$, with $\mathrm{MIC}$ values of 0.78 and 1.5 $\mu \mathrm{g} / \mathrm{mL}$ against $C$. albicans and $C$. tropicalis, respectively, although its organotin precursor $n-\mathrm{Bu}_{3} \mathrm{SnOCH}_{3}$ resulted equally active against $C$. albicans and with a slight better activity against $C$. tropicalis (MIC $0.78 \mu \mathrm{g} / \mathrm{mL}$ ).

C. albicans is an opportunistic pathogen with a great capacity to pass from commensalisms to virulence; in this transition the formation of germ tube is a key feature [37], so we extended our investigation by examining the anti-germ tube formation effect of derivatives $n$ $\mathrm{Bu}_{3} \mathrm{Sn}\left(\mathrm{HtpO}_{2}\right)$ (5), $n-\mathrm{Bu}_{3} \mathrm{SnOCH}_{3}$ and $\mathrm{Ph}_{3} \mathrm{Sn}\left(\mathrm{HtpO}_{2}\right)$ (6) at concentrations equal to $\mathrm{MIC}, 2 \times \mathrm{MIC}$ and $4 \times$ MIC. The germ-tube inhibition is summarized in Table $8 . n-\mathrm{Bu}_{3} \mathrm{Sn}\left(\mathrm{HtpO}_{2}\right)$ possesses a significant activity at concentrations of 3 and $1.5 \mu \mathrm{g} / \mathrm{mL}$, corresponding to $4 \times$ MIC and $2 \times$ MIC, respectively, but a lower activity at $0.78 \mu \mathrm{g} / \mathrm{mL}$, equal to MIC. Its organotin precursor $n$ $\mathrm{Bu}_{3} \mathrm{SnOCH}_{3}$ showed an interesting activity also at MIC concentration of $0.78 \mu \mathrm{g} / \mathrm{mL}$, while $\mathrm{Ph}_{3} \mathrm{Sn}\left(\mathrm{HtpO}_{2}\right)$ resulted not effective as anti germ-tube formation at MIC concentration.

The germ tube formation is a virulence factor that plays a role in the formation of biofilms of C. albicans too [38]. Hence, the antibiofilm properties of $n$ $\mathrm{Bu}_{3} \mathrm{Sn}\left(\mathrm{HtpO}_{2}\right)$ have been also tested, at concentrations ranging from 25 to $0.78 \mu \mathrm{g} / \mathrm{mL}$, against a preformed

Table 7

Antimicrobial activity in vitro, MIC values in $\mu \mathrm{g} / \mathrm{mL}$

\begin{tabular}{|c|c|c|c|c|c|c|c|}
\hline & Compound & $\begin{array}{l}\text { E. coli } \\
\text { ATCC } 25922\end{array}$ & $\begin{array}{l}\text { P. aeruginosa } \\
\text { ATCC } 9027\end{array}$ & $\begin{array}{l}\text { S. aureus } \\
\text { ATCC } 25923\end{array}$ & $\begin{array}{l}\text { S. epidermidis } \\
\text { DSM } 3269\end{array}$ & $\begin{array}{l}\text { C. albicans } \\
\text { ATCC } 10231\end{array}$ & $\begin{array}{l}\text { C. tropicalis } \\
\text { ATCC13803 }\end{array}$ \\
\hline & $n-\mathrm{Bu}_{3} \mathrm{SnOCH}_{3}$ & $>100$ & $>100$ & $>100$ & $>100$ & 0.78 & 0.78 \\
\hline \multirow[t]{2}{*}{5} & $n-\mathrm{Bu}_{3} \mathrm{Sn}\left(\mathrm{HtpO}_{2}\right)$ & $>100$ & 100 & 12.5 & 3.1 & 0.78 & 1.5 \\
\hline & $\mathrm{Ph}_{3} \mathrm{SnOH}$ & $>100$ & $>100$ & $>100$ & $>100$ & $>100$ & $>100$ \\
\hline \multirow[t]{2}{*}{6} & $\mathrm{Ph}_{3} \mathrm{Sn}\left(\mathrm{HtpO}_{2}\right)$ & $>25$ & $>25$ & 6.2 & 3.1 & 0.78 & 0.78 \\
\hline & $\begin{array}{l}\text { Amikacin } \\
\text { Amphotericin B }\end{array}$ & 10 & 5 & 1 & 0.62 & 0.15 & 0.31 \\
\hline
\end{tabular}


Table 8

Inhibition of germ tube formation in C. albicans ATCC 10231

\begin{tabular}{llcll}
\hline \multirow{2}{*}{ Compound } & \multicolumn{3}{c}{ Concentration } \\
\cline { 3 - 5 } & & $4 \times \mathrm{MIC}$ & $2 \times \mathrm{MIC}$ & $\mathrm{MIC}$ \\
\hline $\mathbf{5}$ & $n-\mathrm{Bu}_{3} \mathrm{Sn}\left(\mathrm{HtpO}_{2}\right)$ & $92.1 \pm 0.7$ & $90 \pm 5$ & $35.1 \pm 0.7$ \\
$\mathbf{6}$ & $\mathrm{Ph}_{3} \mathrm{Sn}\left(\mathrm{HtpO}_{2}\right)$ & $83 \pm 4$ & $35 \pm 5$ & ns \\
& $n-\mathrm{Bu}_{3} \mathrm{SnOCH}_{3}$ & $85 \pm 3$ & $75 \pm 3$ & $68 \pm 2$ \\
\hline
\end{tabular}

ns: not significant; the values are the mean of at least three independent determinations; coefficient of variation was less than $15 \%$.

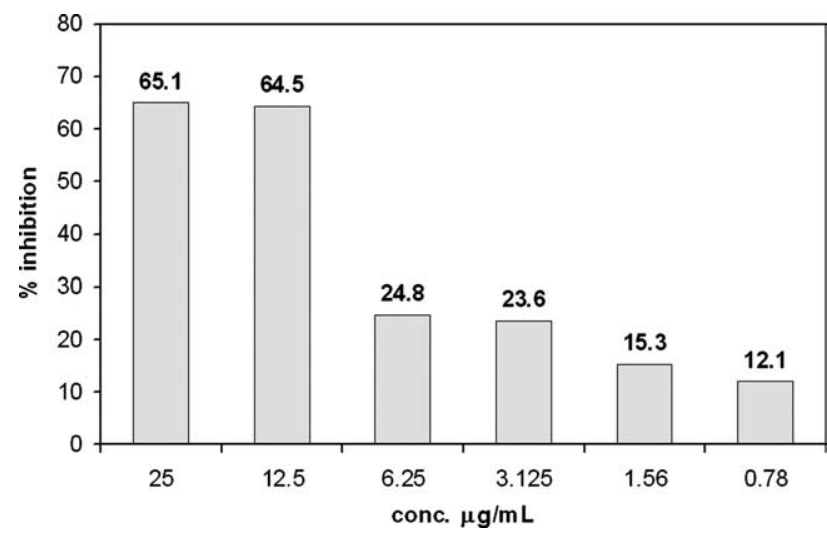

Fig. 5. In vitro inhibition percentages on C. albicans ATCC10231 biofilm by $n-\mathrm{Bu}_{3} \mathrm{Sn}\left(\mathrm{HtpO}_{2}\right)(\mathbf{5})$. Values are the average of at least three independent determinations. Coefficient of variation was less than $15 \%$.

biofilm of $C$. albicans. Although the MIC value was good against the planktonic form of $C$. albicans, we reported a weak activity at concentration equal to MIC against biofilm of the same strain, in fact we only observed an interesting antibiofilm effect at concentrations $16 \times$ MIC or more (see Fig. 5).

Candida albicans infections often involve the formation of biofilms on implanted devices or on tissue surfaces, such infections are difficult to treat, because biofilms are resistant to a wide range of current antifungal agents [39]. There is therefore an urgent need to develop new agents and we think that $n-\mathrm{Bu}_{3} \mathrm{Sn}\left(\mathrm{HtpO} \mathrm{O}_{2}\right)$ might represent a lead compound for developing antifungal and antibiofilm agents.

\section{Acknowledgment}

The financial support of Università di Palermo, Italy, is gratefully acknowledged.

\section{References}

[1] J.M. Salas, M.A. Romero, M.P. Sánchez, M. Quirós, Coord. Chem. Rev. 193-195 (1999) 1119.

[2] J.G. Haasnot, Coord. Chem. Rev. 200-202 (2000) 131.

[3] See for example: (a) L. Pellerito, L. Nagy, Coord. Chem. Rev. 224 (2002) 111; (b) M. Nath, R. Yadav, G. Eng, P. Musingarimi, Appl. Organomet. Chem. 13 (1999) 29;

(c) M. Nath, S. Pokharia, G. Eng, X. Song, A. Kumar, M. Gielen, R. Willem, M. Biesemans, Appl. Organomet. Chem. 18 (2004) 460;

(d) P. Novák, A. Lyčka, I. Císařová, V. Buchta, L. Silva, L. Kolářová, A. Růžička, J. Holeček, Appl. Organomet. Chem. 19 (2005) 500.

[4] M. Abul Haj, M. Quirós, J.M. Salas, R. Faure, J. Chem. Soc., Dalton Trans. (2001) 1798.

[5] M. Abul Haj, J.M. Salas, M. Quirós, J. Molina, R. Faure, J. Mol. Struct. 519 (2000) 165.

[6] S. Orihuela, M.P. Sánchez, M. Quirós, J. Molina, R. Faure, J. Mol. Struct. 415 (1997) 285.

[7] R. Barbieri, G. Ruisi, A. Silvestri, A.M. Giuliani, A. Barbieri, G. Spina, F. Pieralli, F. Del Giallo, J. Chem. Soc., Dalton Trans. (1995) 467.

[8] L.H. Lennette, E.H. Spaulding, P. Truant, in: Manual of Clinical Microbiology, second ed., American Society for Microbiology, Washington, DC, 1974 (Chapter 42).

[9] M.A.S. Alem, J.L. Douglas, Antimicrob. Agents Chemother. 48 (2004) 41.

[10] (a) W.J. Hehre, R. Ditchfield, J.A. Pople, J. Chem. Phys. 56 (1972) 2257 ;

(b) T. Clark, J. Chandrasekhar, P.V.R. Schleyer, J. Comput. Chem. 4 (1983) 294;

(c) R. Krishnam, J.S. Binkley, R. Seeger, J.A. Pople, J. Chem. Phys. 72 (1980) 650;

(d) P.M.W. Gill, B.G. Johnson, J.A. Pople, M.J. Frisch, Chem. Phys. Lett. 197 (1992) 499.

[11] S. Dapprich, I. Komáromi, K.S. Byun, K. Morokuma, M.J. Frisch, J. Mol. Struct. (Theochem) 462 (1999) 1.

[12] (a) N. Godbout, D.R. Salahub, J. Andzelm, E. Wimmer, Can. J. Chem. 70 (1992) 560;

(b) C. Sosa, J. Andzelm, B.C. Elkin, E. Wimmer, K.D. Dobbs, D.A. Dixon, J. Phys. Chem. 96 (1992) 6630.

[13] M.J. Frisch, G.W. Trucks, H.B. Schlegel, G.E. Scuseria, M.A. Robb, J.R. Cheeseman, V.G. Zakrzewski, J.A. Montgomery Jr., R.E. Stratmann, J.C. Burant, S. Dapprich, J.M. Millam, A.D. Daniels, K.N. Kudin, M.C. Strain, O. Farkas, J. Tomasi, V. Barone, M. Cossi, R. Cammi, B. Mennucci, C. Pomelli, C. Adamo, S. Clifford, J. Ochterski, G.A. Petersson, P.Y. Ayala, Q. Cui, K. Morokuma, D.K. Malick, A.D. Rabuck, K. Raghavachari, J.B. Foresman, J. Cioslowski, J.V. Ortiz, A.G. Baboul, B.B. Stefanov, G. Liu, A. Liashenko, P. Piskorz, I. Komaromi, R. Gomperts, R.L. Martin, D.J. Fox, T. Keith, M.A. Al-Laham, C.Y. Peng, A. Nanayakkara, M. Challacombe, P.M.W. Gill, B. Johnson, W. Chen, M.W. Wong, J.L. Andres, C. Gonzalez, M. Head-Gordon, E.S. Replogle, J.A. Pople, Gaussian-98, Revision A.8, Gaussian, Inc., Pittsburgh, PA, 1998.

[14] G. Barone, A. Silvestri, G. Ruisi, G. La Manna, Chem. Eur. J., accepted (DOI: doi:10.1002/chem.200401156).

[15] J.A. Dobado, S. Grigoleit, J. Molina Molina, J. Chem. Soc., Perkin Trans. 2 (2000) 1675.

[16] M. Abul Haj, M. Quirós, J.M. Salas, J.A. Dobado, J. Molina Molina, G. Basallote, M.A. Mánez, Eur. J. Inorg. Chem. (2002) 811.

[17] M. Abul-Haj, M. Quirós, J.M. Salas, Polyhedron 23 (2004) 2373.

[18] M. Abul-Haj, M. Quirós, J.M. Salas, Acta Crystallogr., Sect. C 56 (2000) 934.

[19] R. Barbieri, F. Huber, L. Pellerito, G. Ruisi, A. Silvestri, in: P.J. Smith (Ed.), Chemistry of Tin, Chapman \& Hall, London, 1998, p. 496 (Chapter 14).

[20] See for example: (a) C. Ma, F. Li, Q. Jiang, R. Zhang, J. Organomet. Chem. 689 (2004) 96;

(b) C. Ma, Q. Jiang, R. Zhang, Polyhedron 23 (2004) 779. 
[21] J.A.R. Navarro, M.A. Romero, J.M. Salas, J. Molina, E.R.T. Tiekink, Inorg. Chim. Acta 274 (1998) 53.

[22] J.A.R. Navarro, M.A. Romero, J.M. Salas, J. Chem. Soc, Dalton Trans. (1997) 1001.

[23] J.A.R. Navarro, M.A. Romero, J.M. Salas, M. Quirós, Inorg. Chem. 36 (1997) 3277.

[24] J.A.R. Navarro, M.A. Romero, J.M. Salas, M. Quirós, J. El Bahrauni, J. Molina, Inorg. Chem. 35 (1996) 7829.

[25] J.A.R. Navarro, M.A. Romero, J.M. Salas, R. Faure, X. Solans, J. Chem. Soc, Dalton Trans. (1997) 2321.

[26] D.L. Smith, H.R. Luss, Photogr. Sci. Eng. 20 (1976) 184.

[27] M.H.B. Bol, E.J. Dirks, J.G. Haasnot, J. Reedijk, Inorg. Chim. Acta 180 (1991) 33.

[28] J.A.R. Navarro, J.M. Salas, M.A. Romero, R. Vilaplana, F. Gonzalez-Vílchez, R. Faure, J. Med. Chem. 41 (1998) 332.

[29] J.A.R. Navarro, M.A. Romero, J.M. Salas, M. Quirós, E.R.T. Tiekink, Inorg. Chem. 36 (1997) 4988.
[30] E.J. Dirks, J.G. Haasnot, A.J. Kinneging, J. Reedijk, Inorg. Chem. 26 (1987) 1902.

[31] S. Orihuela, M.P. Sánchez, M. Quirós, D. Martín, R. Faure, Polyhedron 17 (1998) 2477.

[32] R. Willem, I. Verbruggen, M. Gielen, M. Biesemans, B. Mahieu, T.S. Basu Baul, E.R.T. Tiekink, Organometallics 17 (1998) 5758.

[33] G.M. Bancroft, R.H. Platt, Adv. Inorg. Chem. Radiochem. 15 (1972) 59.

[34] G.M. Bancroft, V.G. Kumar Das, T.K. Sham, M.G. Clark, J. Chem. Soc., Dalton Trans. (1976) 643.

[35] Von H. Kriegsmann, H. Geissler, Z. Anorg. Allg. Chem. 323 (1963) 170.

[36] J. Holeček, M. Návdorník, K. Handlír, A. Lyčka, J. Organomet. Chem. 315 (1986) 299.

[37] R.A. Calderone, W.A. Fonzi, Trends Microbiol. 9 (2001) 327.

[38] G.S. Baillie, L.J. Douglas, J. Med. Microbiol. 48 (1999) 671.

[39] L.J. Douglas, Trends Microbiol. 11 (2003) 30. 